Bundesgesundheitsbl 2013 · 56:1557-1564

DOI 10.1007/s00103-013-1844-9

Published online: 24. Oktober 2013

(c) Springer-Verlag Berlin Heidelberg 2013

G. Falkenhorst ${ }^{1} \cdot$ T. Harder ${ }^{1} \cdot$ C. Remschmidt ${ }^{1} \cdot$ M. Terhardt ${ }^{2} \cdot$ F. Zepp ${ }^{3} \cdot$ T. Ledig $^{4}$. S. Wicker ${ }^{5} \cdot$ B. Keller-Stanislawski ${ }^{6} \cdot$ T. Mertens $^{7}$

${ }^{1}$ Immunization Unit, Department for Infectious Disease Epidemiology, Robert Koch Institute, Berlin

2 Medical Practice, Ratingen

${ }^{3}$ Department of Paediatrics and Adolescent Medicine, University

Medical Centre, Johannes Gutenberg University, Mainz

${ }^{4}$ Medical Practice, Ditzingen

${ }^{5}$ Occupational Health Service, University Hospital, Frankfurt/Main

${ }^{6}$ Paul Ehrlich Institute, Langen

${ }^{7}$ Institute of Virology, Ulm University Medical Centre, Ulm

\title{
Background paper to the recommendation for the preferential use of live-attenuated influenza vaccine in children aged 2-6 years in Germany
}

\section{Background}

The German Standing Committee on Vaccination (STIKO) recommends annual vaccination against seasonal influenza for the following target groups: people aged 60 years and over; pregnant women; children, adolescents and adults with an increased risk for severe influenza resulting from an underlying disease; residents of nursing homes; persons at increased risk of exposure or who may act as a possible source of infection for individuals at particular risk under their care (e.g. medical personnel) [1]. The recommendation is aimed at preventing severe illness and death from influenza in these target groups. STIKO does not currently recommend universal influenza vaccination of healthy children and adolescents.

Until September 2012, only trivalent inactivated influenza vaccines (TIV) were available in Germany, including non-adjuvanted and adjuvanted vaccines from several manufacturers [2]. To date, STIKO has recommended annual vaccination with a seasonal influenza vaccine "containing the antigen combination currently endorsed by WHO", without specification of vaccine type. In 2011, a trivalent live-attenuated influenza vaccine (LAIV) was licensed in the European Union (EU) for children and adolescents aged 2-17 years; however, it was not available in Germany until 2012. STIKO evaluated the need for a vaccine-type-specific recommendation for this age group, following its standard operating procedure for the development of evidence-based vaccination recommendations (SOP) [3]. Since this was not a completely new recommendation but an adaptation of the existing recommendation of seasonal influenza vaccination, only the pertinent items of the SOP have been addressed.

Data on efficacy, safety, and reactogenicity of LAIV is available from randomized placebo-controlled trials and from randomized comparative trials with inactivated influenza vaccines. In six placebocontrolled trials, efficacy of trivalent LAIV against laboratory-confirmed influenza in children aged 6-71 months was investigated. Pooled analysis of these studies showed 77\% [95\% confidence interval (CI): 72-80\%] efficacy of LAIV against influenza illness caused by antigenically matched viruses [4]. In addition, effi- cacy, safety, and reactogenicity of LAIV in children and adolescents were directly compared to non-adjuvanted TIV in three randomized trials, so-called head-to-head studies.

The epidemiological and virological characteristics of influenza virus infections show large variations with respect to season and geographic region. Hence, placebo-controlled studies using either LAIV or TIV performed in different populations, in different seasons, and with variable study designs are of limited value for the comparative evaluation of LAIV vs. TIV. Therefore, STIKO based its evaluation on data from the three head-to-head studies in the age group 2-17 years.

\section{The vaccine}

Trivalent Fluenz ${ }^{\oplus}$ (produced by AstraZeneca) was introduced in September 2012 as the only LAIV available in Germany. The identical vaccine was licensed in the United States of America (US) in

Martin Terhardt, Fred Zepp, Thomas Ledig, Sabine Wicker, Thomas Mertens: Members of the German Standing Committee on Vaccination (STIKO). 


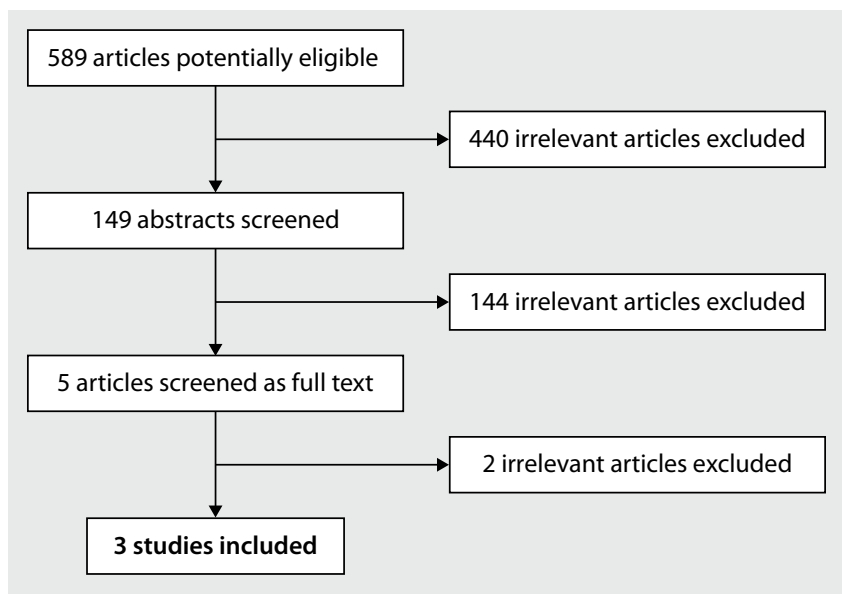

Fig. $1<$ Results of the systematic literature search for studies comparing efficacy/effectiveness of LAIV and TIV in children and adolescents
2003 under the brand name FluMist ${ }^{\oplus}$. In the US, but not yet in the EU, trivalent LAIV has since been replaced by a quadrivalent formulation. In contrast to TIV, which is administered by injection, LAIV has the advantage of nasal application, which may improve acceptance of the annual influenza vaccination among children and their parents.

The vaccine contains reassortants of the cold-adapted 'Ann Arbor' attenuated influenza virus strain, whose genes encoding for hemagglutinin (HA) and neuraminidase (NA) are replaced by the corresponding genes of the respective recommended seasonal influenza virus strains. After nasal application, the vaccine viruses multiply mostly in the upper airways, but-owing to cold adaptationonly to a limited extent in the warmer lower airways. LAIV induces both a systemic and local mucosal immune response [5].

With respect to contraindications, the European summary of product characteristics (SPC) of Fluen $z^{\circledR}$ [6] differs from the prescribing information of FluMist ${ }^{\circledast}$ in the US [7]. While the US prescribing information discourages the use of LAIV in persons with any form of asthma or history of recurrent wheezing, this applies only to persons with severe asthma or current wheezing in the European SPC. Because Fluen $z^{\circledast}$ contains live virus, it must not be used in persons with immunodeficiency or immunosuppression, but may be used in persons who are treated with inhalative or low dose systemic steroids. As vaccinated persons may excrete the vaccine virus, they should avoid close contact with severely immunocompromised persons for
1-2 weeks. Further contraindications include allergies to chicken egg protein or other vaccine components and concomitant treatment with salicylic acid due to the theoretical risk of Reye's syndrome.

\section{Methods}

We performed a systematic literature search for studies comparing efficacy and safety of LAIV and TIV. We searched the databases PubMed, Embase, Cochrane Central Register of Controlled Trials, and Cochrane Database of Systematic Reviews using the search string [influenza AND live AND (vaccine* OR immuniz ${ }^{\star}$ ) AND (efficacy OR effectiveness)]. The resulting list of articles was independently screened for relevance by authors GF and $\mathrm{TH}$, first by title, then by abstract and finally by full text (• Fig. 1). References of articles identified by this procedure were checked for additional relevant publications. Inclusion criteria were: randomized or observational studies including participants aged 2-17 years; immunization with trivalent LAIV based on Ann Arbor strain virus (intervention group) and TIV (comparison group); reporting of one or more of the outcomes rated as 'critical' or 'important' by the STIKO working group on influenza (see $\bullet$ Tab. 2).

We identified two randomized headto-head studies comparing LAIV and TIV in children aged $\leq 6$ years and one study in 6- to 17-year-olds (• Tab. 1). Furthermore, we identified one observational study in children aged 5-18 years [8], which we excluded from further analysis because study participants in the in- tervention group differed substantially in baseline risk for influenza from those in the comparison group (healthy children were vaccinated with LAIV, children with increased risk of influenza due to an underlying chronic condition were vaccinated with TIV). In addition, we found five publications with meta-analyses and/or subgroup analyses of efficacy and safety data from these three studies and placebo-controlled studies of LAIV $[4,9,10,11$, 12 ], which we additionally considered in the evidence appraisal process.

We applied the framework proposed by the Grading of Recommendations Assessment, Development and Evaluation (GRADE) working group (http:// www.gradeworkinggroup.org) to evaluate the quality of the evidence for efficacy and safety of LAIV relative to TIV. The main question was whether children aged 2-17 years with an indication for seasonal influenza vaccination (population) should preferentially be vaccinated with LAIV (intervention) in comparison to TIV (comparison) by considering various clinical endpoints related to efficacy and safety (outcomes). The STIKO working group on influenza ranked outcomes as 'critical' or 'important' regarding decision-making (• Tab. 2). We extracted data on these outcomes from the three randomized head-to-head studies of LAIV and TIV in children and adolescents. We performed a meta-analysis (random-effects model) of the data from the two studies in children $<6$ years of age, but analyzed the study of older children separately because of the heterogenous study populations. We rated the quality of the evidence according to GRADE criteria, using GRADEpro ${ }^{\circledR}$ software.

\section{Results}

\section{Efficacy}

\section{Children up to 6 years of age}

Two of the three identified head-to-head studies included approximately 10,500 children aged 6-71 months [13] and 6-59 months [14], respectively. In these studies, LAIV was 51\% (95\% CI: $24 \%-$ $68 \%)$ and $54 \%$ (95\% CI: 45\%-62\%) more effective against laboratory-confirmed influenza than TIV (• Fig. 2a). 
The pooled relative efficacy of LAIV against hospitalization due to any cause was $11 \%$ (95\% CI: $-16 \%-32 \%)$, i.e. LAIV was slightly, but not statistically significantly more effective than TIV. The endpoint lower respiratory tract illness (LRTI) was only reported by Belshe et al. [14] with a relative efficacy of LAIV of $45 \%$ (95\% CI: 3\%-69\%). No deaths were reported in either study.

These analyses included children under 2 years of age, for whom LAIV was ultimately not licensed due to safety concerns. In a meta-analysis [12] of data from these two studies restricted to children aged 2-6 years, the pooled estimate of the relative efficacy of LAIV vs. TIV against laboratory-confirmed influenza was 53\% (95\% CI: 42\%-62\%), based on 368 influenza cases among nearly 5800 children. Other endpoints were not reported in that particular publication.

\section{Children aged $6-17$ years}

For the age group 6-17 years, the only available data are those from the study by Fleming et al. [15], which included approximately 2200 children with a clinical diagnosis of asthma. In this study, LAIV was 32\% (95\% CI: 3\%-52\%) more effective against laboratory-confirmed influenza than TIV (• Fig. 2b). Age-stratified data from this study were published by Belshe et al. [9], showing similar relative efficacy of LAIV vs. TIV in the age groups 6-11 years (31\%; 95\% CI: $-8 \%-$ $57 \% ; 1376$ subjects) and $12-17$ years (30\%; 95\%CI: $-43 \%-66 \%$; 835 subjects), both of which, however, were not statistically significant. Incidences of LRTI were not reported. Hospitalizations were rare (only two cases) and no deaths occurred.

\section{Safety and reactogenicity}

Safety endpoints ranked as critical or important by STIKO (see $\bullet$ Tab. 2) are reported in different ways in the three publications.

Belshe et al. [14], whose study included children aged 6-59 months, report medically significant wheezing (MSW) within 42 days of vaccination. They observed a significantly higher rate of MSW in previously unvaccinated children aged $<24$ months after vaccination with LAIV

Bundesgesundheitsbl 2013 · 56:1557-1564 DOI 10.1007/s00103-013-1844-9

c) Springer-Verlag Berlin Heidelberg 2013

G. Falkenhorst · T. Harder · C. Remschmidt · M. Terhardt · F. Zepp · T. Ledig · S. Wicker ·

B. Keller-Stanislawski $\cdot$ T. Mertens

Background paper to the recommendation for

the preferential use of live-attenuated influenza vaccine in children aged 2-6 years in Germany

\section{Abstract}

The German Standing Committee on Vaccination (STIKO) recommends seasonal influenza vaccination for children and adolescents with chronic medical conditions that put them at risk for severe influenza illness. In addition to trivalent inactivated influenza vaccines (TIV), a trivalent live-attenuated influenza vaccine (LAIV) was licensed for children and adolescents aged $2-17$ years in the European Union in 2011. Employing the methodology of the Grading of Recommendations Assessment, Development and Evaluation (GRADE) working group, we examined the evidence for efficacy and safety of LAIV relative to TIV to guide STIKO's decision on whether LAIV should be preferentially recommended for at-risk children. In our metaanalysis of data from two randomized trials directly comparing LAIV and TIV in children aged $\leq 6$ years, the protective efficacy of LAIV against laboratory-confirmed influenza was 53\% [95\% confidence interval (CI): 45-61\%] higher than that of TIV. A similar study in individuals aged 6-17 years showed a 32\% (95\% $\mathrm{Cl}$ : 3-52\%) higher efficacy of LAIV. The quality of the evidence for a superior protective efficacy of LAIV against all relevant clinical outcomes was rated 'moderate' for children aged 2-6 years and 'low' for the age group 7-17 years. Regarding safety outcomes, the available data suggest no significant differences between LAIV and TIV. Based on these results, STIKO recommends that LAIV should be used preferentially for influenza vaccination of at-risk children aged 2-6 years. In children and adolescents aged 7-17 years, either LAIV or TIV may be used without specific preference. Possible contraindications and the vaccinee's and his/her guardians' preferences should be taken into account.

Keywords

Influenza - Vaccination · Children · Standing committee on vaccination (STIKO) · Germany

\section{Hintergrundpapier zur Empfehlung einer bevorzugten Anwendung von attenuiertem Influenza-Lebendimpfstoff bei 2-bis 6-jährigen Kindern in Deutschland}

\section{Zusammenfassung}

Die Ständige Impfkommission (STIKO) empfiehlt die saisonale Influenza-Impfung für Kinder und Jugendliche mit chronischen Krankheiten, die ein erhöhtes Risiko für eine schwere Erkrankung an Influenza mit sich bringen. Neben den trivalenten InfluenzaTotimpfstoffen (TIV) wurde 2011 für 2- bis 17-Jährige ein trivalenter attenuierter Influenza-Lebendimpfstoff (LAIV) in der Europäischen Union zugelassen. Anhand der Methodik der Grading of Recommendations Assessment, Development and Evaluation (GRADE) Working Group haben wir die Evidenz für die Effektivität und Sicherheit von LAIV im Vergleich zu TIV untersucht, als Entscheidungsgrundlage für eine mögliche präferenzielle Empfehlung von LAIV durch die STIKO. In unserer Metaanalyse der Daten aus 2 randomisierten Vergleichsstudien von LAIV und TIV bei Kindern $\leq 6$ Jahren war die Schutzwirkung von LAIV gegen laborbestätigte Influenza um 53\% [95\%-Konfi- denzintervall (KI): 45-61\%] höher als die von TIV. Eine ähnliche Studie mit 6- bis 17-Jährigen zeigte eine um 32\% (95\%-KI: 3-52\%) höhere Effektivität von LAIV. Die Qualität der Evidenz für eine bessere Effektivität von LAIV gegen alle klinisch relevanten Endpunkte wurde für 2- bis 6-Jährige als „,moderat" eingestuft, für 7- bis 17-Jährige als „,niedrig". Signifikante Sicherheitsunterschiede zwischen LAIV und TIV fanden sich nicht. Aufgrund dieser Ergebnisse empfiehlt die STIKO, Kinder im Alter von 2-6 Jahren mit einer Indikation für die Influenza-Impfung bevorzugt mit LAIV zu impfen. Bei 7- bis 17-Jährigen können LAIV und TIV gleichwertig verwendet werden, wobei mögliche Kontraindikationen und die Wünsche des Impflings bzw. der Eltern zu berücksichtigen sind.

Schlüsselwörter Influenza · Impfung · Kinder · Ständige Impfkommission (STIKO) · Deutschland 


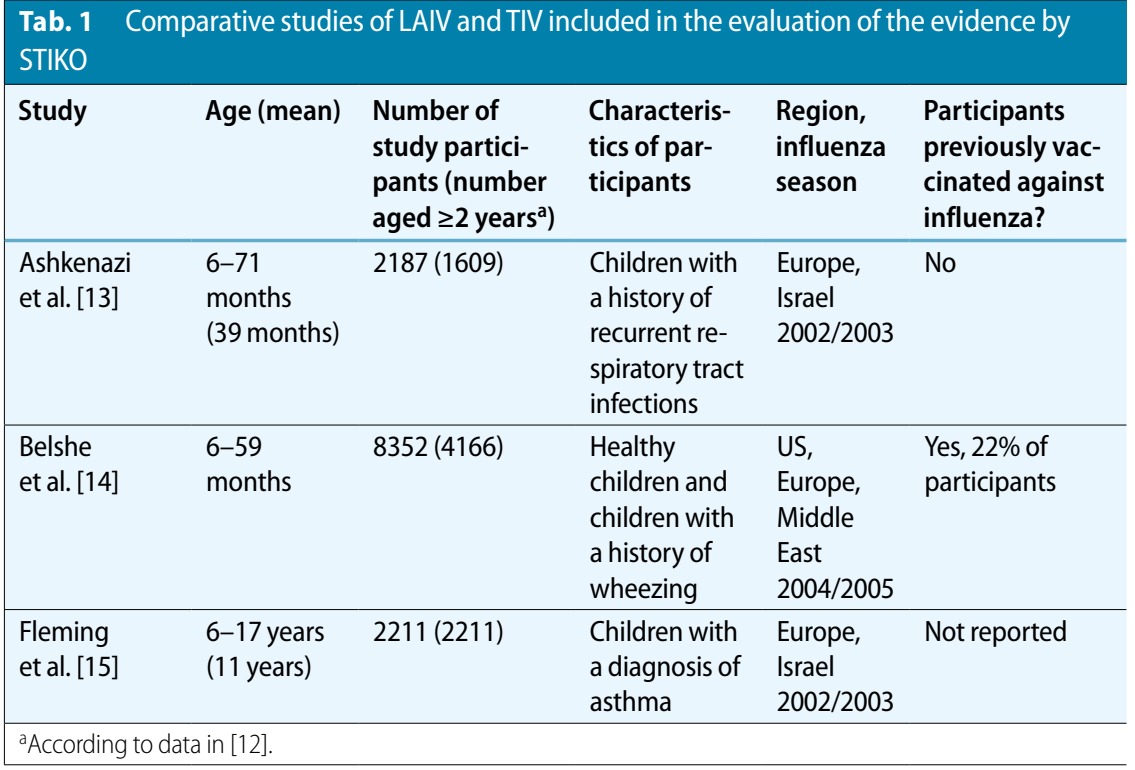

Tab. 2 Outcomes evaluated for grading the evidence for efficacy and safety of LAIV in children and adolescents aged $2-17$ years

\begin{tabular}{|ll}
\hline EFFICACY & SAFETY \\
\hline Critical & Critical \\
\hline Laboratory-confirmed influenza & Hospitalization \\
\hline Lower respiratory tract illness (LRTI, any cause) & Medically significant wheezing (MSW) \\
\hline Hospitalization (any cause) & Lower respiratory tract illness (LRTI, any cause) \\
\hline & Unscheduled health care visit \\
\hline & \\
\hline Important & Important \\
\hline Influenza-like illness (ILI) & Wheezing \\
\hline Outpatient attendance (any cause) & Fever $>39.5^{\circ} \mathrm{C}$ \\
\hline Death (any cause) & Myalgia/arthralgia \\
\hline
\end{tabular}

than after vaccination with TIV [risk ratio $(\mathrm{RR})=1.60,95 \%$ CI: $1.05-2.44)$, while rates were similar for children $\geq 24$ months. In addition, MSW and hospitalization within 180 days of vaccination are reported. LAIV-vaccinated children $<12$ months were hospitalized significantly more often in the 180 days after vaccination than TIV-vaccinated children $(\mathrm{RR}=2.33,95 \%$ CI: 1.36-4.01). Incidences of the other safety endpoints of interest (LRTI), unscheduled health care visit, any wheezing, fever $>39.5^{\circ} \mathrm{C}$, myalgia/arthralgia] are not reported. One death occurred in each vaccine group-one due to aspiration of a foreign body and one due to a house fire.

Ashkenazi et al. [13], whose study included children aged 6-71 months, report the occurrence of fever, myalgia, and wheezing within 11 days of vaccination. In addition, wheezing in the period 11-41 days after vaccination is report- ed. Rates of these events were similar after vaccination with LAIV or TIV. No numbers are reported for the endpoints MSW and LRTI; it is only stated in the text that there was no difference in the incidence of bronchospasm, dyspnea, pneumonia, or LRTI. Incidences of hospitalizations and unscheduled health care visits are only reported as efficacy endpoints over the entire influenza season, making it impossible to judge whether they occurred in temporal relation to vaccination. No participants died during the study.

Ambrose et al. [16] analyzed safety data for the subgroup of 1940 children aged 24-71 months with asthma or a history of wheezing who had been included in these two studies. As for healthy children of the same age, the incidence of hospitalizations, MSW, any wheezing, LRTI, fever, and myalgia was similar in LAIV- and TIV-vaccinated children. Regarding other reactogenicity endpoints, the only significant difference was observed for rhinitis/ blocked nose, which affected up to $~ 68 \%$ of children after LAIV and up to $~ 53 \%$ of children after TIV, depending on vaccine dose and study (percentages estimated from graphical presentation in [16]).

Fleming et al. [15] investigated LAIV and TIV in children and adolescents 6-17 years of age with a clinical diagnosis of asthma. Wheezing (reported within 15 days after vaccination) occurred significantly more often after TIV than after LAIV (23.8\% vs. $19.5 \%$ of vaccinees, $\mathrm{p}=0.02$ ); MSW and LRTI are not reported as separate endpoints. Frequencies of asthma exacerbations, unscheduled clinic visits, and hospitalizations in the 42 days after vaccination are displayed as a bar chart only, showing very similar incidences after LAIV and TIV $(\sim 12 \%, \sim 8 \%$, and $<0.5 \%$ ). Fever and myalgia (reported within 15 days after vaccination) occurred with similar frequencies after LAIV and TIV.

Ambrose et al. [11] analyzed combined data on safety and reactogenicity from the above-mentioned studies and from placebo-controlled trials of LAIV. Their analysis shows that a runny or blocked nose is reported significantly more often after LAIV than after TIV, likely resulting from the nasal application of LAIV. Headache and decreased activity or tiredness were reported significantly more often after LAIV than after placebo. The incidence of local reactions to the intramuscular injection of TIV (redness, swelling, pain at the injection site) is not reported in this publication.

Data on adverse events following immunization from the US, where LAIV has been licensed since 2003, have not generated any safety signals, neither in the passive Vaccine Adverse Event Reporting System (VAERS), nor in a postmarketing study including approximately 28,000 children vaccinated with LAIV [17].

\section{Quality of the evidence}

The detailed appraisal of the quality of the available evidence according to the GRADE framework (i.e., the confidence in the effect estimates for each outcome) 


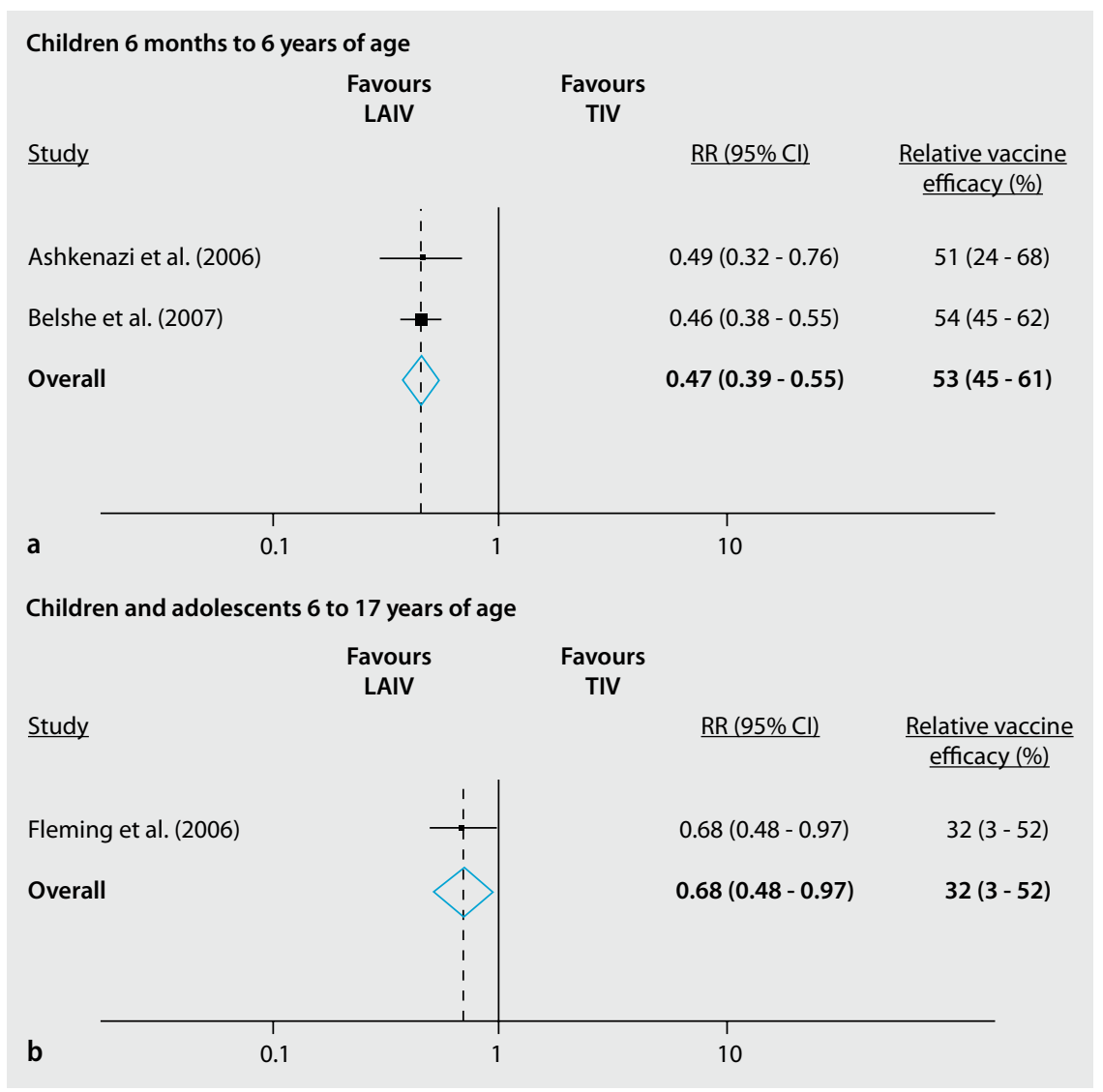

Fig. $2 \Delta$ Efficacy of LAIV and TIV against laboratory-confirmed influenza, based on data from randomized head-to-head studies. (Efficacy estimates were calculated by the authors based on published crude data $[13,14,15]$. They differ slightly in places from the published efficacy estimates). a Children aged 6 months to 6 years. b Children and adolescents aged 6-17 years. RR rate ratio, Relative vaccine efficacy $(1-\mathrm{RR}) * 100$

is presented in the GRADE evidence profiles $(\bullet$ Tab. 3, 4).

\section{Efficacy}

The quality of the evidence for a superior efficacy of LAIV (compared to TIV) against the outcomes 'laboratory-confirmed influenza' and 'lower respiratory tract disease' in children aged 2-6 years is considered 'high'. Evidence quality regarding the outcome 'hospitalization' is considered 'moderate' due to imprecision caused by the low number of cases. According to GRADE, the overall quality of the evidence regarding vaccine efficacy is therefore considered 'moderate' for children aged 2-6 years. For the age group 7-17 years, overall evidence regarding efficacy is considered 'low', since evidence quality for the critical outcome 'hospitalization' is considered 'low' due to very serious imprecision of the effect estimate, which is compatible with considerable

\section{Discussion}

For children aged $\leq 6$ years, two randomized head-to-head studies of LAIV vs. TIV $[13,14]$, conducted in different seasons, demonstrated that LAIV conferred better protection against influenza than TIV. The observed relative efficacy of LAIV vs. TIV was very similar in both studies, $51 \%$ and $54 \%$, respectively (• Fig. 2a). For older children and adolescents aged 7-17 years, the advantage of LAIV was considerably smaller, only marginally statistically significant [relative efficacy $32 \%$ (95\% CI: 3\%-52\%), - Fig. 2b] and based on evidence from one study in one influenza season only [15].

An important question STIKO sought to answer is up to what age LAIV confers better protection against influenza than TIV. In adults, several studies have shown that LAIV provides worse protection than TIV against laboratory-confirmed influenza (see meta-analysis by Belshe et al. [9]). This was also observed in a randomized study comparing LAIV, TIV, and placebo in very young adults with a mean age of 23.3 years (range 18-49 years) [18]. Compared to placebo, vaccine efficacy against laboratory-confirmed influenza was higher for TIV than for LAIV (68\% vs. $36 \%$ ), resulting in a significantly better relative efficacy of TIV vs. LAIV of $50 \%$ (95\% CI: 20\%-69\%).

In summary, the results suggest that the age up to which LAIV provides better protection than TIV lies between 7 and about 18 years. Further specification is not possible on the basis of available data. Immunologically, it appears plausible that protection provided by LAIV decreases with increasing age and recurrent natural interaction of the vaccinee with influenza viruses. As observed with other live vaccines, the attenuated viruses contained in LAIV may be rapidly inactivated in vaccinees with established partial influenzaspecific immunity [5].

Regarding the safety of LAIV, increased rates of medically significant wheezing and hospitalization were observed in children aged $<24$ months after vaccination with LAIV [14]. As a consequence, Fluen $^{\oplus}$ was licensed only for individuals aged at least 2 years. There is no evidence to date for safety concerns regard- 
Tab. 3 GRADE evidence profile for randomized comparative trials of trivalent live-attenuated influenza vaccine (LAIV) and inactivated influenza vaccine (TIV). Children aged $\leq 6$ years

\begin{tabular}{|c|c|c|c|c|c|c|c|c|c|c|c|c|}
\hline Quality & assessme & & & & & & No. of pati & & Effect & & ual- & npor- \\
\hline $\begin{array}{l}\text { No. of } \\
\text { stud- } \\
\text { ies }\end{array}$ & Design & $\begin{array}{l}\text { Risk of } \\
\text { bias }\end{array}$ & $\begin{array}{l}\text { Inconsis- } \\
\text { tency }\end{array}$ & $\begin{array}{l}\text { Indirect- } \\
\text { ness }\end{array}$ & $\begin{array}{l}\text { Im- } \\
\text { preci- } \\
\text { sion }\end{array}$ & $\begin{array}{l}\text { Other } \\
\text { consid- } \\
\text { erations }\end{array}$ & $\begin{array}{l}\text { Vaccina- } \\
\text { tion with } \\
\text { LAIV }\end{array}$ & $\begin{array}{l}\text { Vaccina- } \\
\text { tion with } \\
\text { TIV }\end{array}$ & $\begin{array}{l}\text { Relative } \\
(95 \% \\
\mathrm{Cl})\end{array}$ & Absolute & & \\
\hline
\end{tabular}

Laboratory-confirmed influenza (all strains) (follow-up median 7 months; assessed with: culture/PCR)

\begin{tabular}{|c|c|c|c|c|c|c|c|c|c|c|c|c|}
\hline 2 & $\begin{array}{l}\text { Random- } \\
\text { ized trial }\end{array}$ & $\begin{array}{l}\text { No seri- } \\
\text { ous risk } \\
\text { of bias }\end{array}$ & $\begin{array}{l}\text { No serious } \\
\text { inconsis- } \\
\text { tency }\end{array}$ & $\begin{array}{l}\text { No } \\
\text { serious } \\
\text { indirect- } \\
\text { ness }^{\mathrm{a}}\end{array}$ & $\begin{array}{l}\text { No se- } \\
\text { rious } \\
\text { impre- } \\
\text { cision }\end{array}$ & None & $\begin{array}{l}185 / 4966 \\
(3.7 \%)\end{array}$ & $\begin{array}{l}398 / 4971 \\
(8.0 \%)\end{array}$ & $\begin{array}{l}\text { RR } 0.47 \\
(0.39 \text { to } \\
0.55)\end{array}$ & $\begin{array}{l}42 \text { fewer per } \\
1000 \text { (from } \\
36 \text { fewer to } \\
49 \text { fewer) }\end{array}$ & $\begin{array}{l}+++++ \\
\text { HIGH }\end{array}$ & $\begin{array}{l}\text { CRITI- } \\
\text { CAL }\end{array}$ \\
\hline
\end{tabular}

Lower respiratory tract disease (follow-up 7 months)

\begin{tabular}{|c|c|c|c|c|c|c|c|c|c|c|}
\hline $\begin{array}{l}\text { Random- } \\
\text { ized trial }\end{array}$ & $\begin{array}{l}\text { No seri- } \\
\text { ous risk } \\
\text { of bias }\end{array}$ & $\begin{array}{l}\text { No serious } \\
\text { inconsis- } \\
\text { tency }\end{array}$ & $\begin{array}{l}\text { No } \\
\text { serious } \\
\text { indirect- } \\
\text { ness }\end{array}$ & $\begin{array}{l}\text { No se- } \\
\text { rious } \\
\text { impre- } \\
\text { cision }\end{array}$ & None & $\begin{array}{l}18 / 3916 \\
(0.46 \%)\end{array}$ & $\begin{array}{l}33 / 3936 \\
(0.84 \%)\end{array}$ & $\begin{array}{l}\text { RR } 0.55 \\
(0.31 \text { to } \\
0.97)\end{array}$ & $\begin{array}{l}4 \text { fewer per } \\
1000 \text { (from } \\
0 \text { fewer to } 6 \\
\text { fewer) }\end{array}$ & $\begin{array}{ll}+++++ & \text { CRITI- } \\
\text { HIGH } & \text { CAL }\end{array}$ \\
\hline
\end{tabular}

Hospitalizations (follow-up median 7 months)

2 Random- No seri- No serious ized trial

$\begin{array}{ll}\text { ous risk inconsis- } & \text { serious } \\ \text { ous } & \end{array}$ of bias tency indirect-

Seri- None

$100 / 4543$

$112 / 4524$

RR 0.89

fewer)

\begin{tabular}{|c|c|c|c|c|c|c|c|c|c|c|c|c|}
\hline & & of bias & tency & $\begin{array}{l}\text { indirect- } \\
\text { ness }\end{array}$ & & & & & 1.16) & $\begin{array}{l}8 \text { fewer to } 4 \\
\text { more) }\end{array}$ & ERATE & \\
\hline \multicolumn{13}{|c|}{ Outpatient attendances/health care visits (follow-up 7 months) } \\
\hline 1 & $\begin{array}{l}\text { Random- } \\
\text { ized trial }\end{array}$ & $\begin{array}{l}\text { No seri- } \\
\text { ous risk } \\
\text { of bias }\end{array}$ & $\begin{array}{l}\text { No serious } \\
\text { inconsis- } \\
\text { tency }\end{array}$ & $\begin{array}{l}\text { No } \\
\text { serious } \\
\text { indirect- } \\
\text { ness }\end{array}$ & $\begin{array}{l}\text { No se- } \\
\text { rious } \\
\text { impre- } \\
\text { cision }\end{array}$ & None & $\begin{array}{l}878 / 72476 \\
(1.2 \%)^{c}\end{array}$ & $\begin{array}{l}949 / 71337 \\
(1.3 \%)^{c}\end{array}$ & $\begin{array}{l}\text { RR } 0.91 \\
(0.83 \\
\text { to } 1)\end{array}$ & $\begin{array}{l}1 \text { fewer per } \\
1000 \text { (from } \\
2 \text { fewer to } 0 \\
\text { more) }\end{array}$ & $\begin{array}{l}++++ \\
\text { HIGH }\end{array}$ & $\begin{array}{l}\text { IMPOR- } \\
\text { TANT }\end{array}$ \\
\hline \multicolumn{13}{|c|}{$A E^{\mathrm{d}}$ : Medically significant wheezing (follow-up 180 days) } \\
\hline 1 & $\begin{array}{l}\text { Random- } \\
\text { ized trial }\end{array}$ & $\begin{array}{l}\text { No seri- } \\
\text { ous risk } \\
\text { of bias }\end{array}$ & $\begin{array}{l}\text { No serious } \\
\text { inconsis- } \\
\text { tency }\end{array}$ & $\begin{array}{l}\text { No } \\
\text { serious } \\
\text { indirect- } \\
\text { ness }\end{array}$ & $\begin{array}{l}\text { Se- } \\
\text { rious }^{\mathrm{e}}\end{array}$ & None & $\begin{array}{l}272 / 3495 \\
(7.8 \%)^{f}\end{array}$ & $\begin{array}{l}255 / 3490 \\
(7.3 \%)^{f}\end{array}$ & $\begin{array}{l}\text { RR } 1.06 \\
(0.9 \text { to } \\
1.25)\end{array}$ & $\begin{array}{l}4 \text { more per } \\
1000 \text { (from } 7 \\
\text { fewer to } 18 \\
\text { more) }\end{array}$ & $\begin{array}{l}+++ \\
\text { MOD- } \\
\text { ERATE }\end{array}$ & $\begin{array}{l}\text { CRITI- } \\
\text { CAL }\end{array}$ \\
\hline \multicolumn{13}{|c|}{ AE: Wheezing (follow-up 11 days) } \\
\hline 1 & $\begin{array}{l}\text { Random- } \\
\text { ized trial }\end{array}$ & $\begin{array}{l}\text { No seri- } \\
\text { ous risk } \\
\text { of bias }\end{array}$ & $\begin{array}{l}\text { No serious } \\
\text { inconsis- } \\
\text { tency }\end{array}$ & $\begin{array}{l}\text { No } \\
\text { serious } \\
\text { indirect- } \\
\text { ness }\end{array}$ & $\begin{array}{l}\text { Se- } \\
\text { rious }\end{array}$ & None & $\begin{array}{l}96 / 1032 \\
(9.3 \%)\end{array}$ & $\begin{array}{l}101 / 1020 \\
(9.9 \%)\end{array}$ & $\begin{array}{l}\text { RR } 0.94 \\
(0.72 \text { to } \\
1.22)\end{array}$ & $\begin{array}{l}6 \text { fewer per } \\
1000 \text { (from } \\
28 \text { fewer to } \\
22 \text { more) }\end{array}$ & $\begin{array}{l}+++ \\
\text { MOD- } \\
\text { ERATE }\end{array}$ & $\begin{array}{l}\text { IMPOR- } \\
\text { TANT }\end{array}$ \\
\hline \multicolumn{13}{|c|}{ AE: Fever $\left(>39.5^{\circ} \mathrm{C}\right)$ (follow-up 11 days $^{\mathrm{d}}$ ) } \\
\hline 1 & $\begin{array}{l}\text { Random- } \\
\text { ized trial }\end{array}$ & $\begin{array}{l}\text { No seri- } \\
\text { ous risk } \\
\text { of bias }\end{array}$ & $\begin{array}{l}\text { No serious } \\
\text { inconsis- } \\
\text { tency }\end{array}$ & Serious $^{9}$ & $\begin{array}{l}\text { Se- } \\
\text { rious }\end{array}$ & None & $\begin{array}{l}49 / 961 \\
(5.1 \%)\end{array}$ & $\begin{array}{l}62 / 954 \\
(6.5 \%)\end{array}$ & $\begin{array}{l}\text { RR } 0.78 \\
(0.54 \text { to } \\
1.13)\end{array}$ & $\begin{array}{l}14 \text { fewer per } \\
1000 \text { (from } \\
30 \text { fewer to } 8 \\
\text { more) }\end{array}$ & $\begin{array}{l}++ \\
\text { LOW }\end{array}$ & $\begin{array}{l}\text { IMPOR- } \\
\text { TANT }\end{array}$ \\
\hline \multicolumn{13}{|c|}{ AE: Myalgia (follow-up 11 days) } \\
\hline 1 & $\begin{array}{l}\text { Random- } \\
\text { ized trial }\end{array}$ & $\begin{array}{l}\text { No seri- } \\
\text { ous risk } \\
\text { of bias }\end{array}$ & $\begin{array}{l}\text { No serious } \\
\text { inconsis- } \\
\text { tency }\end{array}$ & $\begin{array}{l}\text { No } \\
\text { serious } \\
\text { indirect- } \\
\text { ness }\end{array}$ & $\begin{array}{l}\text { Se- } \\
\text { rious }\end{array}$ & None & $\begin{array}{l}36 / 632 \\
(5.7 \%)\end{array}$ & $\begin{array}{l}50 / 685 \\
(7.3 \%)\end{array}$ & $\begin{array}{l}\text { RR } 0.78 \\
(0.52 \text { to } \\
1.18)\end{array}$ & $\begin{array}{l}16 \text { fewer per } \\
1000 \text { (from } \\
35 \text { fewer to } \\
13 \text { more) }\end{array}$ & $\begin{array}{l}+++ \\
\text { MOD- } \\
\text { ERATE }\end{array}$ & $\begin{array}{l}\text { IMPOR- } \\
\text { TANT }\end{array}$ \\
\hline \multicolumn{13}{|c|}{ Influenza-like illness } \\
\hline 0 & $\begin{array}{l}\text { No evidence } \\
\text { available }\end{array}$ & & & & & & - & - & - & - & & $\begin{array}{l}\text { IMPOR- } \\
\text { TANT }\end{array}$ \\
\hline \multicolumn{13}{|c|}{ Death } \\
\hline 0 & $\begin{array}{l}\text { No evidence } \\
\text { available }\end{array}$ & & & & & & - & - & - & - & & $\begin{array}{l}\text { IMPOR- } \\
\text { TANT }\end{array}$ \\
\hline \multicolumn{13}{|c|}{ AE: Unscheduled health care visit } \\
\hline 0 & $\begin{array}{l}\text { No evidence } \\
\text { available }\end{array}$ & & & & & & - & - & - & - & & $\begin{array}{l}\text { CRITI- } \\
\text { CAL }\end{array}$ \\
\hline
\end{tabular}


Tab. 4 GRADE evidence profile for randomized comparative trials of trivalent live-attenuated influenza vaccine (LAIV) and inactivated influenza vaccine (TIV). Children and adolescents aged 6-17 years

\begin{tabular}{|c|c|c|c|c|c|c|c|c|c|c|c|c|}
\hline \multicolumn{7}{|c|}{ Quality assessment } & \multicolumn{2}{|c|}{ No. of patients } & \multicolumn{2}{|l|}{ Effect } & \multirow{2}{*}{$\begin{array}{l}\text { Qual- } \\
\text { ity }\end{array}$} & \multirow{2}{*}{$\begin{array}{l}\text { Impor- } \\
\text { tance }\end{array}$} \\
\hline $\begin{array}{l}\text { No. of } \\
\text { stud- } \\
\text { ies }\end{array}$ & Design & $\begin{array}{l}\text { Risk of } \\
\text { bias }\end{array}$ & $\begin{array}{l}\text { Inconsis- } \\
\text { tency }\end{array}$ & $\begin{array}{l}\text { Indirect- } \\
\text { ness }\end{array}$ & $\begin{array}{l}\text { Impre- } \\
\text { cision }\end{array}$ & $\begin{array}{l}\text { Other } \\
\text { con- } \\
\text { sider- } \\
\text { ations }\end{array}$ & $\begin{array}{l}\text { Vaccina- } \\
\text { tion with } \\
\text { LAIV }\end{array}$ & $\begin{array}{l}\text { Vaccina- } \\
\text { tion with } \\
\text { TIV }\end{array}$ & $\begin{array}{l}\text { Relative } \\
(95 \% \mathrm{CI})\end{array}$ & Absolute & & \\
\hline \multicolumn{13}{|c|}{ Laboratory-confirmed influenza (all strains) (follow-up 7 months; assessed with: culture/PCR) } \\
\hline 1 & $\begin{array}{l}\text { Random- } \\
\text { ized trial }\end{array}$ & $\begin{array}{l}\text { No seri- } \\
\text { ous risk } \\
\text { of bias }\end{array}$ & $\begin{array}{l}\text { No serious } \\
\text { inconsis- } \\
\text { tency }\end{array}$ & $\begin{array}{l}\text { No seri- } \\
\text { ous indi- } \\
\text { rectness }\end{array}$ & $\begin{array}{l}\text { No } \\
\text { serious } \\
\text { impre- } \\
\text { cision }\end{array}$ & None & $\begin{array}{l}50 / 1109 \\
(4.5 \%)\end{array}$ & $\begin{array}{l}73 / 1102 \\
(6.6 \%)\end{array}$ & $\begin{array}{l}\text { RR } 0.68 \\
(0.48 \text { to } \\
0.97)\end{array}$ & $\begin{array}{l}21 \text { fewer per } \\
1000 \text { (from } \\
2 \text { fewer to } \\
34 \text { fewer) }\end{array}$ & $\begin{array}{l}++++ \\
\text { HIGH }\end{array}$ & $\begin{array}{l}\text { CRITI- } \\
\text { CAL }\end{array}$ \\
\hline \multicolumn{13}{|c|}{ Hospitalizations (follow-up 7 months) } \\
\hline 1 & $\begin{array}{l}\text { Random- } \\
\text { ized trial }\end{array}$ & $\begin{array}{l}\text { No seri- } \\
\text { ous risk } \\
\text { of bias }\end{array}$ & $\begin{array}{l}\text { No serious } \\
\text { inconsis- } \\
\text { tency }\end{array}$ & $\begin{array}{l}\text { No seri- } \\
\text { ous indi- } \\
\text { rectness }\end{array}$ & $\begin{array}{l}\text { Very se- } \\
\text { rious }^{\mathrm{a}}\end{array}$ & None & $\begin{array}{l}0 / 1109 \\
(0 \%)\end{array}$ & $\begin{array}{l}2 / 1102 \\
(0.18 \%)\end{array}$ & $\begin{array}{l}\text { RR } 0.20 \\
(0.01 \text { to } \\
4.13)\end{array}$ & $\begin{array}{l}1 \text { fewer per } \\
1000 \text { (from } \\
2 \text { fewer to } 6 \\
\text { more) }\end{array}$ & $\begin{array}{l}++ \\
\text { LOW }\end{array}$ & $\begin{array}{l}\text { CRITI- } \\
\text { CAL }\end{array}$ \\
\hline \multicolumn{13}{|c|}{ Outpatient attendances/health care visits (follow-up 7 months) } \\
\hline 1 & $\begin{array}{l}\text { Random- } \\
\text { ized trial }\end{array}$ & $\begin{array}{l}\text { No seri- } \\
\text { ous risk } \\
\text { of bias }\end{array}$ & $\begin{array}{l}\text { No serious } \\
\text { inconsis- } \\
\text { tency }\end{array}$ & $\begin{array}{l}\text { No seri- } \\
\text { ous indi- } \\
\text { rectness }\end{array}$ & $\begin{array}{l}\text { No } \\
\text { serious } \\
\text { impre- } \\
\text { cision }\end{array}$ & None & $\begin{array}{l}607 / 86714 \\
(0.7 \%)^{b}\end{array}$ & $\begin{array}{l}599 / 85571 \\
(0.7 \%)^{b}\end{array}$ & $\begin{array}{l}\text { RR } 1.0 \\
(0.89 \text { to } \\
1.12)\end{array}$ & $\begin{array}{l}0 \text { fewer per } \\
1000 \text { (from } \\
1 \text { fewer to } 1 \\
\text { more) }\end{array}$ & $\begin{array}{l}++++ \\
\text { HIGH }\end{array}$ & $\begin{array}{l}\text { IMPOR- } \\
\text { TANT }\end{array}$ \\
\hline \multicolumn{13}{|c|}{$\mathrm{AE}^{\mathrm{c}}$ : Wheezing (follow-up 15 days) } \\
\hline 1 & $\begin{array}{l}\text { Random- } \\
\text { ized trial }\end{array}$ & $\begin{array}{l}\text { No seri- } \\
\text { ous risk } \\
\text { of bias }\end{array}$ & $\begin{array}{l}\text { No serious } \\
\text { inconsis- } \\
\text { tency }\end{array}$ & $\begin{array}{l}\text { No seri- } \\
\text { ous indi- } \\
\text { rectness }\end{array}$ & $\begin{array}{l}\text { No } \\
\text { serious } \\
\text { impre- } \\
\text { cision }\end{array}$ & None & $\begin{array}{l}206 / 1056 \\
(19.5 \%)\end{array}$ & $\begin{array}{l}249 / 1046 \\
(23.8 \%)\end{array}$ & $\begin{array}{l}\text { RR } 0.82 \\
(0.7 \text { to } \\
0.97)\end{array}$ & $\begin{array}{l}43 \text { fewer per } \\
1000 \text { (from } \\
7 \text { fewer to } \\
71 \text { fewer) }\end{array}$ & $\begin{array}{l}++++ \\
\text { HIGH }\end{array}$ & $\begin{array}{l}\text { IMPOR- } \\
\text { TANT }\end{array}$ \\
\hline \multicolumn{13}{|c|}{ AE: Fever ( $\left.>39.5^{\circ} \mathrm{C}\right)$ (follow-up 15 days) } \\
\hline 1 & $\begin{array}{l}\text { Random- } \\
\text { ized trial }\end{array}$ & $\begin{array}{l}\text { No seri- } \\
\text { ous risk } \\
\text { of bias }\end{array}$ & $\begin{array}{l}\text { No serious } \\
\text { inconsis- } \\
\text { tency }\end{array}$ & $\begin{array}{l}\text { No seri- } \\
\text { ous indi- } \\
\text { rectness }\end{array}$ & $\begin{array}{l}\text { Seri- } \\
\text { ous }^{\text {d }}\end{array}$ & None & $\begin{array}{l}7 / 1000 \\
(0.7 \%)\end{array}$ & $\begin{array}{l}10 / 909 \\
(1.1 \%)\end{array}$ & $\begin{array}{l}\text { RR } 0.64 \\
(0.24 \text { to } \\
1.66)\end{array}$ & $\begin{array}{l}4 \text { fewer per } \\
1000 \text { (from } \\
8 \text { fewer to } 7 \\
\text { more) }\end{array}$ & $\begin{array}{l}+++ \\
\text { MOD- } \\
\text { ERATE }\end{array}$ & $\begin{array}{l}\text { IMPOR- } \\
\text { TANT }\end{array}$ \\
\hline \multicolumn{13}{|c|}{ AE: Myalgia (follow-up 15 days) } \\
\hline 1 & $\begin{array}{l}\text { Random- } \\
\text { ized trial }\end{array}$ & $\begin{array}{l}\text { No seri- } \\
\text { ous risk } \\
\text { of bias }\end{array}$ & $\begin{array}{l}\text { No serious } \\
\text { inconsis- } \\
\text { tency }\end{array}$ & $\begin{array}{l}\text { No seri- } \\
\text { ous indi- } \\
\text { rectness }\end{array}$ & $\begin{array}{l}\text { No } \\
\text { serious } \\
\text { impre- } \\
\text { cision }\end{array}$ & None & $\begin{array}{l}184 / 1057 \\
(17.4 \%)\end{array}$ & $\begin{array}{l}202 / 1025 \\
(19.7 \%)\end{array}$ & $\begin{array}{l}\text { RR } 0.88 \\
(0.74 \text { to } \\
1.06)\end{array}$ & $\begin{array}{l}24 \text { fewer per } \\
1000 \text { (from } \\
51 \text { fewer to } \\
12 \text { more) }\end{array}$ & $\begin{array}{l}++++ \\
\text { HIGH }\end{array}$ & $\begin{array}{l}\text { IMPOR- } \\
\text { TANT }\end{array}$ \\
\hline \multicolumn{13}{|c|}{ Influenza-like illness } \\
\hline 0 & $\begin{array}{l}\text { No evidence } \\
\text { available }\end{array}$ & & & & & & - & - & - & - & & $\begin{array}{l}\text { IMPOR- } \\
\text { TANT }\end{array}$ \\
\hline \multicolumn{13}{|c|}{ Lower respiratory tract disease } \\
\hline 0 & $\begin{array}{l}\text { No evidence } \\
\text { available }\end{array}$ & & & & & & - & - & - & - & & $\begin{array}{l}\text { CRITI- } \\
\text { CAL }\end{array}$ \\
\hline \multicolumn{13}{|l|}{ Death } \\
\hline 0 & $\begin{array}{l}\text { No evidence } \\
\text { available }\end{array}$ & & & & & & - & - & - & - & & $\begin{array}{l}\text { IMPOR- } \\
\text { TANT }\end{array}$ \\
\hline \multicolumn{13}{|c|}{ AE: Medically significant wheezing } \\
\hline 0 & $\begin{array}{l}\text { No evidence } \\
\text { available }\end{array}$ & & & & & & - & - & - & - & & $\begin{array}{l}\text { CRITI- } \\
\text { CAL }\end{array}$ \\
\hline \multicolumn{13}{|c|}{ AE: Unscheduled health care visit } \\
\hline 0 & $\begin{array}{l}\text { No evidence } \\
\text { available }\end{array}$ & & & & & & - & - & - & - & & $\begin{array}{l}\text { CRITI- } \\
\text { CAL }\end{array}$ \\
\hline
\end{tabular}


ing healthy children and children with well-controlled asthma in the licensed age range from 2 to 17 years. However, the size of currently available studies is not sufficient to detect rare adverse events. Moreover, precautions are expressed for the use of LAIV in children with significant obstructive lung disease. Non-standardized reporting of safety endpoints hampered pooled analysis of safety data from different studies.

The three comparative trials of LAIV and TIV included healthy children as well as children with a history of respiratory infections or asthma. For other groups of children for whom STIKO recommends annual influenza vaccination, e.g., with chronic cardiovascular, neurological, liver, or kidney diseases and diabetes, no specific data are available. Children with "serious chronic disease (including progressive neurologic disease)" were excluded from studies [13] and [15], although this is not mentioned as an exclusion criterion in the study [14]. It seems plausible that the findings on efficacy and safety of LAIV also apply to these patient groups, who can be considered immunocompetent. For another important target group for influenza vaccination, namely children with immunocompromising conditions, LAIV is contraindicated.

STIKO concluded in view of the available evidence that a preferential recommendation of LAIV is warranted for children aged 2-6 years, but not for older children. It should be noted that in the US, unlike in the EU, LAIV is licensed from age 2 to 49 years; however, there is no preferential recommendation of either LAIV or TIV for any age group in the US [19].

\section{Conclusion}

Based on the assessment of the available evidence, STIKO recommends that children aged 2-6 years with an indication for seasonal influenza vaccination should preferentially receive LAIV, unless contraindicated. For children and adolescents aged 7-17 years, either LAIV or TIV may be used without preference, taking into consideration potential contraindications and the vaccinee's and his/her guardians' preference. The nasal application route of LAIV may possibly increase acceptance of annual influenza vaccination in the target group of children and adolescents with risk factors for severe influenza.

\section{Corresponding address}

\section{G. Falkenhorst}

Immunization Unit, Department for Infectious Disease Epidemiology, Robert Koch Institute Seestr. 10, 13353 Berlin

Germany

FalkenhorstG@rki.de

Conflict of interest. The corresponding author states the following: M. Terhardt has given non-productrelated talks on influenza vaccination that were sponsored by AstraZeneca. S. Wicker has received honoraria for non-product-related talks on influenza vaccination from GlaxoSmithKline, Sanofi Pasteur, AstraZeneca and Novartis and has participated in workshops about health care workers and vaccination sponsored by Abbot. F. Zepp has participated in a collaborative research project on pandemic influenza vaccines (GlaxoSmithKline, GSK) and has participated as a member/expert in advisory boards on pandemic and seasonal influenza for Chiron, Novartis and GSK. He has given nonproduct-related talks and was moderator or (co-)chairperson in symposia on influenza vaccination sponsored by GSK, InfectoPharm and Novartis. The associated travel expenses have been financed or refinanced by these companies. All other authors declare that they have no conflicts of interest.

\section{References}

1. Recommendations of the Standing Committee on Vaccination (STIKO) at the Robert Koch Institute (2013). http://www.stiko.de/en

2. Paul Ehrlich Institute (2013) Vaccines for Influenza (Flu). http://www.pei.de/EN/medicinal-products/ vaccines-human/influenza-flu/influenza-flu-node. html. Accessed: 28 Aug 2013

3. German Standing Committee on Vaccinations (STIKO) (2012) Standard operating procedure for the systematic development of vaccination recommendations. http://www.rki.de/EN/Content/Prevention/Vaccination/methodology/SOP.pdf Accessed: 2 Oct 2013

4. Rhorer J, Ambrose CS, Dickinson S et al (2009) Efficacy of live attenuated influenza vaccine in children: a meta-analysis of nine randomized clinical trials. Vaccine 27:1101-1110

5. Murphy BR, Coelingh K (2002) Principles underlying the development and use of live attenuated cold-adapted influenza $A$ and $B$ virus vaccines. Viral Immunol 15:295-323

6. European Medicines Agency (2013) Fluenz ${ }^{\circledR}$ summary of product characteristics. http://www. ema.europa.eu/docs/en_GB/document_library/ EPAR - Product_Information/human/001101/ WC500103709.pdf. Accessed: 3 Sep 2013

7. US Food and Drug Administration (2013) Prescribing Information for FluMist ${ }^{\circledast}$. http://www.fda.gov/ downloads/BiologicsBloodVaccines/Vaccines/ApprovedProducts/UCM123743.pdf. Accessed: 3 Sep 2013
8. Piedra PA, Gaglani MJ, Kozinetz CA et al (2007) Trivalent live attenuated intranasal influenza vaccine administered during the 2003-2004 influenza type $A(H 3 N 2)$ outbreak provided immediate, direct, and indirect protection in children. Pediatrics 120:e553-e564

9. Belshe RB, Toback SL, Yi T, Ambrose CS (2010) Efficacy of live attenuated influenza vaccine in children 6 months to 17 years of age. Influenza Other Respir Viruses 4:141-145

10. Ambrose CS, Levin MJ, Belshe RB (2011) The relative efficacy of trivalent live attenuated and inactivated influenza vaccines in children and adults. Influenza Other Respir Viruses 5(2):67-75

11. Ambrose CS, Yi T, Falloon J (2011) An integrated, multistudy analysis of the safety of Ann Arbor strain live attenuated influenza vaccine in children aged 2-17 years. Influenza Other Respir Viruses 5(6):389-397

12. Ambrose CS, Wu X, Knuf M, Wutzler P (2012) The efficacy of intranasal live attenuated influenza vaccine in children 2 through 17 years of age: a metaanalysis of 8 randomized controlled studies. Vaccine 30(5):886-892

13. Ashkenazi S, Vertruyen A, Aristegui J et al (2006) Superior relative efficacy of live attenuated influenza vaccine compared with inactivated influenza vaccine in young children with recurrent respiratory tract infections. Pediatr Infect Dis J 25:870-879

14. Belshe RB, Edwards KM, Vesikari T et al (2007) Live attenuated versus inactivated influenza vaccine in infants and young children. N Engl J Med 356:685696

15. Fleming DM, Crovari P, Wahn U et al (2006) Comparison of the efficacy and safety of live attenuated cold-adapted influenza vaccine, trivalent, with trivalent inactivated influenza virus vaccine in children and adolescents with asthma. Pediatr Infect Dis J 25:860-869

16. Ambrose CS, Dubovsky F, Yi T et al (2012) The safety and efficacy of live attenuated influenza vaccine in young children with asthma or prior wheezing. Eur J Clin Microbiol Infect Dis 31(10):2549-2557

17. Toback SL, Ambrose CS, Eaton A et al (2013) A postlicensure evaluation of the safety of Ann Arbor strain live attenuated influenza vaccine in children 24-59 months of age. Vaccine 31:1812-1818

18. Monto AS, Ohmit SE, Petrie JG et al (2009) Comparative efficacy of inactivated and live attenuated influenza vaccines. N Engl J Med 361:1260-1267

19. US Centers for Disease Control and Prevention (2013) Summary Recommendations: Prevention and Control of Influenza with Vaccines: Recommendations of the Advisory Committee on Immunization Practices - (ACIP)—United States, 2013-14. http://www.cdc.gov/flu/professionals/ acip/2013-summary-recommendations.htm. Accessed: 28 Aug 2013 